\title{
Impact of HIV/AIDS in the family on children's quality of life
}

\author{
Toha Muhaimin
}

Department of Population and Biostatistics, Faculty of Public Health University of Indonesia

\begin{abstract}
Abstrak
Tujuan: Epidemi AIDS berdampak negatif terhadap kehidupan sosial-ekonomi keluarga. Tujuan penelitian ini menilai dampak HIV/AIDS dalam keluarga terhadap kualitas hidup anak, dan mengidentifikasi faktor-faktor yang ikut berperan.

Metode: Studi ini menggunakan data hasil survei HIVIAIDS yang dilakukan Pusat Penelitian Kesehatan-UI PPKUI (2007) di tujuh propinsi, terdiri dari 379 rumah tangga (RT) dengan HIV dan 370 RT tanpa HIV. Kualitas hidup anak diukur pada usia 5-11 tahun (anak pra-remaja) melalui variabel komposit tiga dimensi (pendidikan, lingkungan sosial dan aktifitas fisik) dengan nilai kategori 'kurang baik' dan 'baik'. Regresi logistik ganda dilakukan untuk menilai pengaruh faktor HIVIAIDS, faktor rumah tangga dan faktor anak terhadap kualitas hidup anak.

Hasil: Pertama, adanya HIVIAIDS dalam RT, peluang risiko kualitas hidup anak menjadi 'kurang baik' sebesar 1,59 kali dibanding anak dari RT tanpa HIVIAIDS. Kedua, bila anak dalam RT tersebut perempuan, peluang risiko kualitas hidup anak tersebut 'kurang baik'sebesar 1,50 kali dibanding bila anak tersebut laki-laki. Ketiga, anak yang mendapat praktek pengasuhan 'kurang baik', peluang risiko kualitas hidup anak 'kurang baik' 1,55 kali dibanding bila anak mendapat pengasuhan 'baik'. Keempat, pada anak usia lebih muda (5-7 tahun), peluang risiko kualitas hidup anak 'kurang baik'sebesar 1,60 kali dibanding bila anak berusia lebih tua (8-11 tahun).

Kesimpulan: Studi ini menunjukkan bahwa adanya salah satu anggota keluarga yang terinfeksi HIV dalam rumah tangga berpengaruh negatif terhadap kualitas hidup anak pra-remaja. Pengaruh negatif tersebut lebih besar apabila anak tersebut perempuan, kurang mendapat pengasuhan, dan berusia lebih muda. (Med J Indones 2010; 19:280-6)
\end{abstract}

\begin{abstract}
Aim: An AIDS epidemic has a negative social and economic impact to the families. The aim of the study is to explore the impact of HIV/AIDS in the family to the quality of life of the children, including other factors that might interfere.

Methods: The study utilized the data of a survey conducted by the Health Research Center of the University of Indonesia (2007), in seven provinces consisting of 379 households (HH) with HIV and 370 HH without HIV. Child's quality of life was measured at ages 5 to 11 years (pre-adolescent) using a composite of three variables (education, social environment, and physical activity), and was scored as 'poor' and 'good'. Multiple logistic regression was performed to examine the impact of HIV/AIDS, household and child factor towards the child's quality of life.

Results: The presence of an HIV/AIDS patient in the HH increases the risk of poor quality of life 1.59 times compared to the risk in $\mathrm{HH}$ without HIV/AIDS. If the child is a female, the risk of poor quality of life increases 1.50 times compared to male children. A child who is poorly taken care of faces a 1.55 times higher risk of poor quality of life compared to children who are well taken care of. In younger children (5-7 yrs) the risk of poor quality of life increases 1.60 times compared to older children (8-11 yrs).

Conclusion: The study showed that when a member of the family is infected with HIV, it will negatively affect the quality of life of a pre-teen child in that family. This negative effect is higher when the child is a female, does not receive proper care, and of younger age. (Med J Indones 2010; 19:280-6)
\end{abstract}

Key words: child care, children's quality of life, impact of HIVIAIDS

The first case of Acquired Immunodeficiency Syndrome (AIDS) was reported by Gottlieb and his colleagues in Los Angeles, in June 1981. ${ }^{1}$ The Human Immunodeficiency Virus (HIV) infections is the cause of AIDS, and has become a global pandemic. ${ }^{2}$

The cumulative number of reported AIDS cases in Indonesia up to March 2010 was 20.564. In addition to that, there were 40.321 cases of HIV infection reported through 226 Voluntary Counseling and Testing (VCT) clinics nationwide. The AIDS male/female ratio was 3:1, differing from $4: 1$ ratio of previous years, offering a glimpse of the progress of the epidemic in Indonesia. ${ }^{3}$

The global epidemic of HIV/AIDS has had a profound effect in the social lives, family lives and individual lives of Indonesians, particularly Indonesian children. Because of this disease, many children are facing problems with health, education, economy, and psychosocial issues. All these will lead to a disturbance in the quality of life during growth. 
A study by Biggar (2000) in New Orleans showed that the academic performance of children with HIV positive mothers were lower (2.06 grade average) than those with uninfected mothers (2.34 grade average). This decline was attributed to the higher frequency of missed attendance. $^{4}$

This study explores the impacts of the presence of HIV in the family to the quality of life of the child, including other factor that might interfere such as head of the household, child and caregiver.

\section{METHOD}

\section{Data source and study design}

This study uses secondary data from a study performed by The Health Research Center of University of Indonesia (PPK-UI), titled Families and Children Affected by HIV/ AIDS in Indonesia: A National Situation Analysis, 2007 (from here on will be referred to as PPKUI AIDS Study 2007), which was financially supported by UNICEF. This study was performed in sever provinces: North Sumatera, West Kalimantan, DKI Jakarta, West Java, East Java, Bali and Papua. This was a cross sectional study.

\section{Population and study sample}

In this study, a child is defined as a person between 5 to 11 years old (pre-teen). There are two populations in this study, the Index population and the Reference Population. The Index Population consists of households with at least one HIV infected person, alive or deceased, that lived with at least one child in the household. The Reference Population consists of comparative households confirmed to be free of HIV infection, with at least one child as a member of the household. We have matched the Reference Population with the Index Population, so that comparisons are made between populations in close residential proximity to each other and similarity of the level of education and age of the head of the households between these populations.

The samples in this study were collected from the PPKUI AIDS Study 2007, consisting of 749 households; 379 households with HIV and 370 households without HIV. Data collection was performed through interviews with three types of respondents in a household: head of the household, caregiver and one chosen child (if there is more than one child between the ages of 5 and 11 years old). The interviewers were local Non Government Organization (NGO) staffs who were trained to perform the interviews.

\section{Study instruments}

This study used filled out questionnaires from the PPKUI AIDS Study 2007. To specifically extract the data on child's quality of life, we refer to the instrument to measure child's life quality available in Health Related Quality of Life Generic Instruments. ${ }^{5}$ Due to the limited variables provided in the questionnaires of the PPKUI AIDS Study 2097, to determine the quality of life of the child we have decided on three domains: education, social environment (from here on to be referred to as 'environment'), and physical activity in free time (from here on to be referred to as 'activity'). The domain of education was constructed out of 3 questions, the domain of environment out of 3 questions, and the domain of activity out of 7 questions, in accordance to the secondary data provided by the PPKUI AIDS Study 2007.

\section{Data analysis}

Bivariate analysis will be presented in cross tables with Chi square test to explore the correlations between the main independent variable (HIV status in the household) and the dependent variable (child's quality of life), or between two independent variables to clarify existing analyses. We used multiple logistic regression to explore the impact of the main variable (HIV status in the household) and other variables of the head of the household, caregiver and child.

\section{RESULTS}

\section{Head of the household characteristics}

The heads of the household in both groups (household with HIV and household without HIV) were mostly male $(70 \%$ and $90 \%)$, but the percentage of female heads of the household was higher in the households with HIV (three time higher). The percentage of unemployment in households with HIV was also higher (nearly twice as high). The socio-economical status of both populations did not differ significantly, although it was higher in the population with HIV.

\section{Child characteristics}

The percentage of certain categories (sex, age, and education) in both populations did not differ significantly. Almost half of the children were boys, and half were girls in both populations. In households with HIV, the percentage of children without education was slightly higher than in households without HIV (3\% vs. 1\%). A significant difference was found in the social status 
variable, where more children have lost a parent in the population with HIV than in the population without HIV (more than four times more). Another significant difference was the relationship of the child to the head of the household, where in the population with HIV more children were grandchildren to the head of the household (twice the percentage of the population without HIV).

\section{Caregiver characteristics}

The variables describing the characteristics of the caregiver did not vary significantly between the two populations. These variables are sex, education, and employment status. In short, we can conclude that almost all (90\%) of the caregivers were women, half of them have completed an educational level of senior high school or higher, almost half of them were employed, and half of them were homemakers.

Age wise, in families with HIV, the percentage of caregivers who were older than 50 years old were three times higher than in families without HIV $(20.8 \%$ compared to $6.6 \%$ ). Caregivers in the families with HIV had better knowledge about HIV/AIDS compared to caregivers in families without HIV; $72 \%$ of caregivers in families with HIV had 'adequate' knowledge compared to $49 \%$ of caregivers in families without HIV.

However, in the population with HIV the percentage of 'inadequate' care giving practices was higher (35\%) than in the population without HIV $(25 \%)$.

\section{Child's quality of life}

Theresults show thatmostofthe childrenhavea 'poor'quality of life in the population with HIV as well as the children in the population without HIV. Even so, the percentage of children with 'poor' quality of life in the population with HIV is higher $(75.5 \%)$ than in the population without HIV $(64.3 \%)$; this is statistically significant ( $p, 0.01)$.

Table 1. Percentile of Child Based on Household Status and Quality of Life

\begin{tabular}{|c|c|c|c|c|}
\hline & \multicolumn{2}{|c|}{$\begin{array}{l}\text { Child's Quality of } \\
\text { Life }(\%)\end{array}$} & OR & $\mathrm{p}$ \\
\hline Category & Poor & Excellent & & \\
\hline HH with HIV $(n=379)$ & 75.5 & 24.5 & 1.71 & 0.001 \\
\hline HH without HIV $(n=370)$ & 64.3 & 35.7 & & \\
\hline
\end{tabular}

Table 1 shows that the risk of quality of life becoming poor increases almost two folds (OR 1.71) in households with HIV compared to children in households without
HIV. Keep in mind that the OR is a crude calculation because we only used the main exposure variable (the presence/absence of an HIV infected person in the household) while other variables were omitted.

Because a child's quality of life may also be affected by various confounding variables, we have to explore the correlation of the quality of life with other variables in the household such as the head of the household, the child, and the caregiver.

\section{HIV/AIDS in the family and the child's quality of life}

In this next section we will analyze the factors that determine the child's quality oflife, from the independent variables that may potentially be confounding variables (result from stratification analysis) of the main independent variable (HIV status in the household), by designing a multivariate model with multiple logistic regression.

To create a multiple logistic regression we performed a screening of all the independent variables (predictors) that are considered as confounders and have a correlation with the quality of life of the child. Screening was performed by evaluating the correlation of every independent variable (head of the household, child, and caregiver) with the dependent variable (child's quality of life) through a simple logistic regression (two variables). Independent variables with a significant value of $p$ Wald $<0.25$ will be chosen as a candidate in the multivariate analysis that will be performed next. ${ }^{15}$ Table 6 describes the results of the screening evaluation.

There are seven independent variables (besides the main independent variable, which is the HIV status in a household) that fulfill the requirements to be entered into the multiple logistic regression analysis $(p<0.25)$. They are: Employment status of the head of the household, benefits received, sex of the child, age of the child, age of the caregiver, employment status of the caregiver, and care giving practices.

These seven variables (which are now considered confounders) along with the main independent variable will be evaluated through multiple logistic regression with the Enter method.

The next step is to eliminate the confounders that have a $p$ value of more than 0.05 , starting from the variable with the highest $p$ value. The same thing is performed until there are no more variables with a $p$ value higher than 0.05 . 
The end model candidate from the selection process of the independent variables consists of the main variable (HIV status in the household) and three other independent variables (sex of the child, care giving practices, and age of the child).

Table 2. End Model Candidate of the Multiple Logistic Regression of the Child's Quality of Life and the Independent Variables/ Predictors in Pre-Teen Children

\begin{tabular}{lcccccccc}
\hline Predictor Variables & B & S.E. & Wald & df & Sig. & $\operatorname{Exp}(\beta)$ & $\begin{array}{c}95 \% \text { C.I.for } \\
\operatorname{EXP}(\beta)\end{array}$ \\
\hline & & & & & & & Lower & Upper \\
\hline HIV status in HH & .465 & .164 & 8.043 & 1 & .005 & 1.592 & 1.154 & 2.195 \\
Sex of the child & .408 & .163 & 6.249 & 1 & .012 & 1.503 & 1.092 & 2.069 \\
$\begin{array}{l}\text { Care giving } \\
\text { practices }\end{array}$ & .437 & .193 & 5.094 & 1 & .024 & 1.547 & 1.059 & 2.261 \\
Age of the child & .469 & .165 & 8.088 & 1 & .004 & 1.598 & 1.157 & 2.209 \\
Constant & -2.810 & .404 & 48.320 & 1 & .000 & .060 & & \\
\hline
\end{tabular}

Information: HIV status in the HH ( $1=$ HH HIV,$+ 0=$ HH HIV-); Sex of the child $(1=$ girl, $\mathrm{X}=0$ boy); Care giving practices ( $1=$ poor, $0=$ excellent); Age of child $(1=5-7$ yo, $0=8-11$ yo).

The next step is to look for the interaction between the main independent variable and the other independent variables, as well as the interaction between every independent variable that may be entered into the model. There are six possible variable interaction, they are: HIV status with the child's sex, HIV status with the care giving practices, HIV status and the child's age, The child's sex and the care giving practice, the child's sex and the child's age, the care giving practices and the child's age. The interaction variable that are entered in the model are interactions that have a significance value of $p<0.05$. It turns out that there is no interaction variable that fulfills this requirement.

To further categorize the three independent variables (the child's sex, the child's age, and the care giving practices) in the model into confounders or variables that determine the quality of life of the child, we performed an elimination process and assessed the changes of the odds ratio value of the main independent variable (OR of the HIV status in the household), before and after each of the variables were taken out of the model.

There are no changes in odds ratio higher than $10 \%$, therefore the three variables cannot be considered as confounding variables but are variables that affect the child's quality of life.

Now we can perform a final model of multiple logistic regression of the child's quality of life and other determining variables. This is described in Table 3 .
Table 3. Final Model of the Multiple Logistic Regression of the Child's Quality of Life and Predictor Variables in the Household

\begin{tabular}{lcccccc}
\hline Predictor Variable & B & S.E. & Wald & df & Sig. & $\operatorname{Exp}(\beta)$ \\
\hline HH with HIV & 0.465 & 0.164 & 8.043 & 1 & 0.005 & 1.592 \\
Female child & 0.408 & 0.163 & 6.249 & 1 & 0.012 & 1.503 \\
Poor care giving practices & 0.437 & 0.193 & 5.094 & 1 & 0.024 & 1.547 \\
Age 5-7 years old & 0.469 & 0.165 & 8.088 & 1 & 0.004 & 1.598 \\
Constant & -2.81 & 0.404 & 48.32 & 1 & 0.000 & 0.060 \\
\hline
\end{tabular}

Information: $\operatorname{Exp}(\beta)$ value in this model is the Odds Ratio value of the corresponding variable

The final model of the above multiple logistic regression shows that: First, the presence of an HIV/AIDS patient in the household increases the risk of poor quality of life 1.59 times compared to the risk in household without HIV/AIDS. Second, if the child is a female, the risk of poor quality of life increases 1.50 times compared to male children. Third, a child who is poorly taken care of faces a 1.55 times higher risk of poor quality of life compared to children who are well taken care of. Fourth, in younger children (5-7 yo) the risk of poor quality of life increases 1.60 times compared to older children (8-11 yo).

\section{DISCUSSION}

Although this study covers a wide geographic area (7 out of 33 provinces), it only represents a small percentage of the total population of Indonesia (21\%). Therefore this study cannot be used as a representation for the whole of Indonesia. The study was performed in the seven provinces with the highest prevalence of HIV/AIDS.

The collection of samples was not performed completely at random (except in Jakarta), therefore these samples cannot represent the whole population of the seven provinces. It is, however, almost impossible to collect random samples considering the nature of the research subject. AIDS is an extremely sensitive subject. Oftentimes, families with HIV/AIDS will not disclose information of their status, hence preventing proper sampling frame.

\section{HIV/AIDS in the family and child's life quality}

The main result of this study showed that life quality of a child in a family with HIV is less good than of a child in a family without HIV, with a higher risk (1.7 times higher) and a statistical significance $(\mathrm{p}=0.001)$. This showed that the presence of HIV infection in the household will decrease the quality of life of a child in 
that household. The results of this study are in accordance to results of other studies in various countries, as elaborated below.

As explained previously, the child's life quality was measured by three dimensions, they are: education, social environment, and physical activity. Jianhua et al. (2006), in their study in China, reported that the high absence rate in children affected by HIV/AIDS was $23 \% .6$ Biggar (2000) also reported that academically, children with HIV positive mothers had a grade average of 2.06 compared to those with HIV negative mothers with a grade average of $2.34 .^{4}$ This decline was attributed to the high absence rate. However, it must be noted that in both of these studies the person with HIV/ AIDS was the mother of the child, and this might have a specific impact on the child's life quality.

A Chinese study by Xu et al. (2006-2007) also showed a decline in academic performance. This decline occurred in $12 \%$ of the children affected by HIV/AIDS, after their parent fell ill or passed away because of the disease. More than half of the children affected by HIV/AIDS (63.8\%) received aid from the government or other organizations due to economical conditions of the family, conditions of care for the child and the unsupportive attitude of society towards the child.?

The social environment is one of the dimensions of the quality of life measured in this study. It describes the presence of a stigma and discrimination towards an infected person and their family. The negative and unsupportive social environment was also reported by World Vision (2005). This study reported that in Uganda, 14 out of 16 children who were orphaned by HIV/AIDS were treated discriminatively; also, it was reported that $85 \%$ of families in Kaswa (Uganda) experienced discrimination. 8 Jinhua et al. (2006) reported that $40 \%$ of children affected with HIV/AIDS in China felt disliked by their friends, were easily offended, and felt lonely. ${ }^{6}$

The decline of life quality of the child in an HIV infected household in this study was thought to be caused by factors relating to the head of the household, the child, and the caregiver.

From the stratification analysis (not presented in this study) we have found that there was a consistence in the correlation between HIV/AIDS in the family and the decline of the child's quality of life, in all factors concerning the head of the household, child, and caregiver. Even so, the stratification analysis showed that these factors did not control each other. Therefore, it needs to be determined which factors are truly correlated, which are the determinant of the confounders, or the possibility of interaction. For that we performed a multivariate analysis using multiple logistic regression.

This analysis shows that the presence of an HIV/AIDS patient in the family is not the only variable in determining the child's quality of life. The three other variables that lower the child's life quality are the sex of the child, care giving practices, and the age of the child. The three variables show similar significance in their correlation with the child's quality of life, they each have an adjusted odds ratio (Exp $\beta$ value) of 1.5-1.6. This means that a 5-7 years old female child who is poorly taken care of in a household with HIV/AIDS faces a risk 1.5-1.6 higher of a poor quality of life compared to 8-11 years old male children who are well take care of without HIV/AIDS in the household.

From this finding we see that the best operational strategic program would be to prevent HIV/AIDS in the household and to improve care giving practices or child care.

Preventive efforts for HIV have been widely promoted, by the government, the society, NGOs in Indonesia, specifically in these seven provinces. However, efforts to improve care giving practices, specifically in HIV/ AIDS families, have not been applied, whether by the government nor Indonesian NGO's specifically those in the 7 provinces. Therefore, the development of a child care program is extremely important in the efforts to mitigate the impact of HIV/AIDS in the family on a child's quality of life. This program needs to be initiated by the government, society, or NGOs that delve in the eradication of HIV/AIDS.

Efforts of mitigating the effects of HIV/AIDS on a child's life should also be done through the development of a pioneering program that deals with a child's education, betterment of health and nutrition, as well as economical empowerment. I accordance to the national strategy of AIDS eradication, these efforts should be applied by society and NGOs and supported by the government.

\section{Gender factor and child's quality of life}

We have calculated an odds ratio of 1.5 in the female child variable in this study, indicating that a female child stand a 1.5 times higher risk of poor life quality compared to a male child. One of the reasons for this could be because our society still favors the male in various aspects, such as education, and basic needs such as food and clothing. 
In a family economically impacted by HIV/AIDS (Mahal and Rao, 2005), as usually happens, oftentimes the male child gets priority of receiving an education, because he is expected to become the head of a household someday. Whereas a female child will be forced to quit school and assist in providing for the family, such as in the informal sector as child labor. Oftentimes this is the coping mechanism a family would adopt. ${ }^{9}$ This, of course, will decline the female child's quality of life. In fact, according to Rozana (2007), child labors are vulnerable to trafficking, exploitation and abuse.10 Other than that, female child labors, who usually work informal jobs such as house maid, are not protected under any occupational laws because the law forbids child labor hence they are not recognized occupationally. ${ }^{11}$

It is clear that in a household condition such as stated above, a female child's quality of life will decline.

\section{Care giving factor and child's quality of life}

According to the logistical regression analysis, another factor that affects a child's quality of life is the care the child receives. The caregiver in this study is the person who is responsible for the child's daily life for the last year and lives with the child in the same household (a caregiver in this study does not to the maid).

There are three important things in care giving in this study that affect the child's quality of life; they are the care giving practices, educational level of the caregiver, and the sex of the caregiver.

The aspects of care giving that were explored in this study were activities that have to do with education, clothing, nutrition, religion, psychosocial support, and care during child's illness. The more complete these aspects are covered, the better the child's quality of life is expected to be.

This study shows that children who receive 'poor' care face a 1.5 times higher risk of a poor quality of life than children who receive 'good' care.

Good care giving practices are, of course, those that complete a child's needs in the aspects of education, clothing, nutrition, religious practices, and psychosocial support. In a family with a low economical status this is difficult to fulfill. Therefore, in the betterment of care giving practices, aside from an educational program, the family's economical status should also be im- proved. This way, there is a better chance of improving the child's quality of life.

To formulate a model of care for a child in an HIV/AIDS affected family, an applied research should be conducted, because an applied research would allow care giving intervention to be applied to the family, and this family would reap the immediate benefit of this type of research. The results of this research may become a model of care giving in a family affected by HIV/AIDS.

\section{Age factor and child's quality of life}

For analysis, we have divided the age factor into two groups, 5-7 years old and 8-11 years old. This study shows that there is a correlation between a child's age and his/her quality of life. The OR (adjusted) is 1.6, which means that a younger child (5-7 year old) has a 1.6 times higher risk of lower quality of life than an older child (8-11 year old). The pre-teen years are 5-11 years old, this research shows that the older the child is, the smaller the proportion of children with poor quality of life. For example, at age 5 the proportion is $86.8 \%$, and this proportion decreases as the age increases. At age 11 the proportion is $62.3 \%$. We can see through linear regression analysis that the correlation between age and 'poor' quality of life has a Pearson correlation coefficient (r) of -0.95 with $p=0.001$. This means that there is a strong negative correlation, nearing $100 \%$. In conclusion we see that in a pre-teen child, the older the age the lower proportion of 'poor' quality of life. In other words, the older the child is, the better the child's quality of life.

In conclusions, the results of this study show that when a member of the family is infected with HIV, it will negatively affect the quality of life of a pre-teen child in that family. This negative effect also occurs when the child is a female, of younger age, and does not receive proper care. This study indicates a necessity to develop a child care program in the family to reduce the socio-economical impacts of HIV/ AIDS in the family on the child's quality of life.

\section{Acknowledgments}

I extend my gratitude's to Pusat Studi Kesehatan Universitas Indonesia (PPKUI) for assisting me in this study, and also to UNICEF Jakarta for allowing me to use the data collected by PPKUI through their research funded by UNICEF. I would also like to thank Prof. Budi Utomo, Prof. Samsuridjal Djauzi and Prof. Sudarto Ronoatmodjo, who have graciously assisted me during my research. 


\section{REFFERENCES}

1. Centers for Disease Control and Prevention (1999), Pneumocystic Pneumonia - Los Angeles, MMWR, Supplements, March 3 1999/48 (LMRK); 77-81. (htpp://www.cdc. gov/mmwr/preview/mmwrhtml/lmrk0077.htm - Downloaded 11 January 2007).

2. Klatt, Edward C. (2007), Pathology of AIDS, version 18, Florida State University, College of Medicine, USA.

3. Departemen Kesehatan, Ditjen Pengendalian Penyakit dan Penyehatan Lingkungan, (2010), Laporan Triwulan Situasi Perkembangan HIV dan Kasus AIDS di Indonesia last updated 31 Maret 2010, Jakarta

4. Biggar, H., Rex Forehand, Meridith W. Chance, Edward Morse, Patricia Morse, and Mary Stock (2000), The Relationship of Maternal HIV Status and Home Variables to Academic Performance of African American Children, AIDS and Behavior; Sep 2000; 4,3 :241-52

5. Oksuz, Ergun and Simten Malham (2006), Compendium of Health Related Quality of Life Generic Instruments, Basken University, Ankara, Turkey

6. Jianhua, Y., C. Chun, L. Kangmai, X. Wenging, K. Legins, L. Hui, J. Tao, H. Houbao, Y. Fei, L. Tangfeng (2006), The Assessment Impact of HIV/AIDS on Children in China, Januari 2006.
7. Xu, Tao, Z. Wu, S.Duan, W. Han, and K. Rao (2010), The Situation of Children Affected by HIV/AIDS in Southwest China: Schooling, Physical Health and Interpersonal Relationships, JAIDS Journal of Acquired Immune Deficiency Syndrome: February 2010; 53 (): S104-S110/ (http://journals.lww.com/ jaids/Fulltext/2010/02011/The_Situation_of_Children_Affected_by_HIV_AIDS_in.18.aspx - Diunduh 17 Agustus 2010)

8. World Vision, (2005), Violence against Children Affected by HIV/AIDS: A case study of Uganda. A contribution to the United Nations Study on Violence Against Children, World Vision International-Africa Office 2005

9. Mahal, Ajay and Bhargavi Rao. HIV/AIDS epidemic in India: An economic perspective, Indian J Med Res. 2005; 121: $582-600$

10. Rozana, Ellin (2007), Buruh Anak: Realitas Persoalan dan Kebijakan, Jurnal Perempuan, 2007; 56: 25-39.

11. Subiyantoro, Eko Bambang (2007), Buruh Anak Perempuan: Bekerja Tanpa Jaminan Hukum, Jurnal Perempuan, 2007; 56: 41-52.

12. Zheng, Tongzhang (1998), Principles of Epidemiology, Yale University, School of Public Health.

13. Selvan, Mano S., and Anura V. Kurpad (2004), Primary prevention: Why focus on children \& young adolescents?, Indian J Med Res. 2004; 120(6): 511-9 